\title{
Climate Adaptation by International Multidisciplinary Knowledge Exchange: Sharing Challenges and Solutions in ClimateCafés in the Philippines and Peru
}

\author{
Floris C. Boogaard and C. E. (Lotte) de Jong
}

\section{Contents}

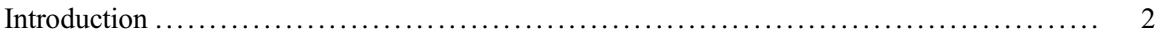

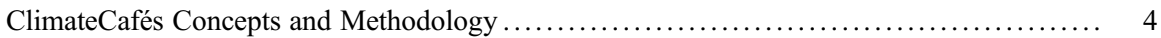

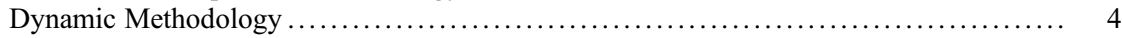

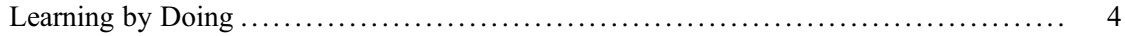

Development of ClimateCafés over Time .................................. 5

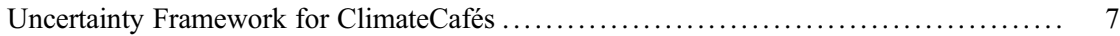

Content and Uncertainty $\ldots \ldots \ldots \ldots \ldots \ldots \ldots \ldots \ldots \ldots \ldots \ldots \ldots \ldots \ldots \ldots \ldots \ldots \ldots \ldots \ldots \ldots \ldots \ldots \ldots, 12$

ClimateCafés and Generating Ideas ............................................ 16

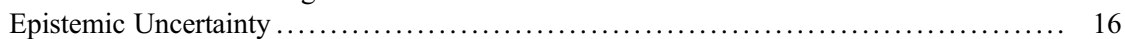

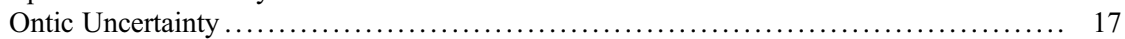

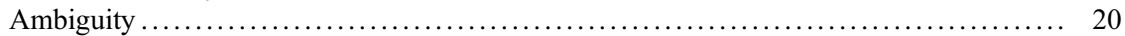

Decision-Making $\ldots \ldots \ldots \ldots \ldots \ldots \ldots \ldots \ldots \ldots \ldots \ldots \ldots \ldots \ldots \ldots \ldots \ldots \ldots \ldots \ldots \ldots \ldots \ldots \ldots \ldots \ldots \ldots \ldots, 22$

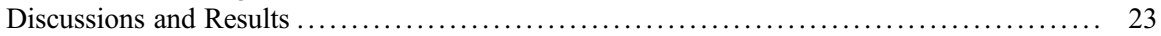

The Reduction of Uncertainties ......................................... 23

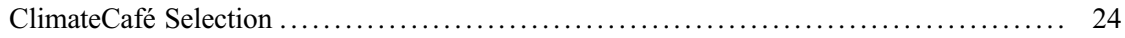

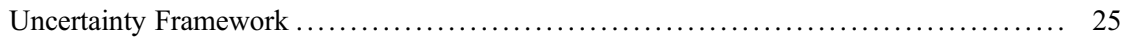

ClimateCafé for Sharing Knowledge, Raising Awareness, and Capacity Building ....... 25

ClimateCafé and the Quadruple Helix ....................................... 26

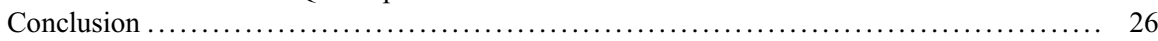

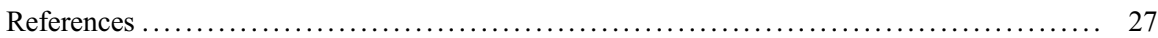

F. C. Boogaard $(\bowtie)$

Hanze University of Applied Sciences Groningen, Groningen, The Netherlands

Global Center on Adaptation, Energy Academy Europe, Groningen, The Netherlands

e-mail: floris@noorderruimte.nl

C. E. L. de Jong

Global Center on Adaptation, Energy Academy Europe, Groningen, The Netherlands

Environmental Science Group, Wageningen University \& Research, Wageningen, The Netherlands 


\section{Abstract}

Effects of climate change in cities are evident and are expected to increase in the future, demanding adaptation. In order to share knowledge, raise awareness, and build capacity on climate adaptation, the first concept of a "ClimateCafe" has been utilized since 2012 in 25 events all over the world. In 8 years ClimateCafé grew into a field education concept involving different fields of science and practice for capacity building in climate change adaptation. This chapter describes the need, method, and results of ClimateCafés and provides tools for organizing a ClimateCafé in a context-specific case. Early ClimateCafés in the Philippines are compared with the ClimateCafé in Peru to elucidate the development of this movement, in which one of the participants of ClimateCafé Philippines 2016 became the co-organizer of ClimateCafé Peru in 2019. The described progress of ClimateCafés provides detailed information on the dynamic methodological aspects, holding different workshops. The workshops aim at generating context-specific data on climate adaptation by using tools and innovative data collection techniques addressing deep uncertainties that come with climate change adaptation. Results of the workshops show that context-specific, relevant, multidisciplinary data can be gathered in a short period of time with limited resources, which promotes the generation of ideas that can be used by local stakeholders in their local context. A ClimateCafé therefore stimulates accelerated climate action and support for adaptation solutions, from the international and the local, from the public and private sector, to ensure we learn from each other and work together for a climate resilient future. The methodology of ClimateCafé is still maturing and the evaluation of the ClimateCafés over time leads to improvements which are applied during upcoming ClimateCafés, giving a clear direction for further development of this methodology for knowledge exchange, capacity building, and bridging the gap between disciplines within climate adaptation.

\section{Keywords}

Climate adaptation · Capacity building $\cdot$ ClimateCafés $\cdot$ Climate action $\cdot$ Knowledge Exchange $\cdot$ Learning by doing

\section{Introduction}

Cities are becoming increasingly vulnerable to climate change, resulting in an urgent need to make them more resilient. Climate change impacts such as increased heat, drought, and flooding forces action to be taken within heavily urbanized areas where the battle of space is a daily struggle (IPCC 2019). Next to climate change, socioeconomic aspects such as urbanization, population growth, and irregular settling aggregate the pressure for space. Urbanization usually leads to degradation of the urban dense area, by, e.g., soil sealing and air, water, and soil pollution, with the result that humans are exposed to floods, contaminants, and loss of biodiversity. 
Some of the biggest challenges are to bring down city temperatures, fight water shortages, protect homes and businesses from damage by flooding, and increase biodiversity within small budgets and timeframes.

The challenges for cities require action. Globally, there is a strong call for climate change adaptation to address and take action on these current and future challenges (GCA 2019). Climate change adaptation emphasizes on the deep connection between human and natural systems and affirms that both systems are interconnected. Climate change adaptation, from a decision takers' point of view, means making decisions under deep uncertainty (Haasnoot et al. 2013). Deep uncertainties come in several forms. Roughly three types of uncertainty can be defined: epistemic uncertainty, ontic uncertainty, and uncertainty due to ambiguity (Brugnach et al. 2008). Each of them requiring different approaches and when combined, they can lead toward adaptive decision-making.

The first type of uncertainty, epistemic uncertainty, is related to a lack of knowledge. This can, and is, being addressed by data collection and research; make a research plan and follow a methodology (Zandvoort et al. 2018). With advancing methodologies and the help of technology, epistemic uncertainty can be reduced. The second type of uncertainty, ontic uncertainty, is about the unpredictability of certain phenomena due to chaotic behavior of complex systems and is sometimes referred to as structural uncertainty. An example of this is the unpredictability of the future. For this, models are used which can provide a range of possible futures but can never predict what will happen exactly. Subsequently, co-production of scenarios provides insight in what could happen to deal with an unpredictable future (Wollenberg et al. 2000). Adaptation pathways are another example of a methodology to work with the acknowledgment of ontic uncertainty toward a desired future (Bloemen et al. 2018). The third type is related to "truth-seeking" through multiple perspectives, ambiguity. This type of uncertainty addresses the way multiple perspectives on "how the world works" exist. This is usually done with stakeholder engagement and co-production methods (Bremer and Meisch 2017) to either come to a collective understanding or to understand diverse knowledge frames. It is been hypothesized that, for effective climate change adaptation, all three types of uncertainty should be addressed.

Addressing the three types of uncertainty is complemented by sharing knowledge, raising awareness, and building capacity on climate change adaptation. First of all, sharing knowledge prevents reinventing the wheel. Climate change is a global issue; however climate change adaptation is often local. The local adaptation initiatives applied in a certain area could be applicable in another area as well. By sharing knowledge on context-specific adaptation, one can create new knowledge and add to existing knowledge. Secondly, raising awareness on climate change adaptation complements the uptake of adaptation measures. When aware of a situation, common thoughts on how to deal with this situation can improve the willingness to adapt. The willingness to adapt bridges the gap between theoretical ideas and actual implementation and uptake of ideas. When combined, sharing knowledge and raising awareness leads to capacity building. Capacity building, through participation, is crucial across multiple disciplines and generations in order to adapt. 
The global magnitude of climate change, the wide range of impacts of climate change, and the local emphasis of climate change adaptation makes capacity to be built among a wide range of disciplines. A wide range of actors, sectors, and fields are involved in climate change adaptation, in which actors are individual or groups of stakeholders which are influenced by or have influence on climate change adaptation; sectors are water, infrastructure, finance, and nature; and the fields are where the interaction occurs, such as in the policy domain or in the educational domain. A so-called "quadruple helix" approach (Carayannis and Campbell 2009) addresses the actors, sectors, and fields. In a quadruple helix, actors of governments, universities, civic society, and private parties from different sectors work together. The novel aspect of this triple helix is that future generations, students from the university, are given a voice and access to the adaptation debate. Adaptation is about the future, and therefore, youth can be considered as an important stakeholder.

\section{ClimateCafés Concepts and Methodology}

\section{Dynamic Methodology}

ClimateCafé is a flexible and dynamic field education concept involving different fields of science and practice for capacity building in climate change adaptation, but it is not a fixed formula. ClimateCafés are used as a method to address local wicked issues of climate change adaptation in multiple parts of the globe. The aim of a ClimateCafé is knowledge exchange, raising awareness, and building capacity in urban areas targeting young professionals in a "learning by doing" interaction concept. The ClimateCafé methodology is dynamic, implying the overall aim is supplemented by specific objectives for each ClimateCafé, making it tailor-fitted to each context and challenge.

\section{Learning by Doing}

ClimateCafés are "learning by doing" events. Learning by doing is a methodology, which emphasizes the advantage of learning through experiencing. Visualized by "Edgar Dale's Pyramid of Learning," he argues that people remember more of "what they do," compared to "what they read," which results in the ability to define and create new knowledge contrary to repeating what one has learned. Although Edgar Dale's Pyramid of Learning is in discrepancy (Masters 2013), learning by doing is still considered as a more effective way of learning, compared to listening, reading, or watching videos, such as MOOCs (Koedinger et al. 2015). Furthermore, learning by doing has increasingly been mentioned in relation with climate change adaptation and the accompanied deep uncertainties. It has been argued that learning by doing addresses "unknown unknowns," enabling common learning of participants and coordinators during a ClimateCafé. 


\section{Development of ClimateCafés over Time}

ClimateCafés are events which are originally organized as an optional part of the bachelor program of Civil Engineering from the Hanze University of Applied Sciences, Groningen, and Water Management from the Applied University of Rotterdam (both in the Netherlands). The events have been called by different names such as City Climate Scan (Boogaard et al. 2016; Heikoop and Boogaard 2018; Boogaard et al. 2020; ClimateCafeNews Page 2019; Boogaard and Venvik 2019; Climate Scan 2019), River Scan, Climate Scan, Flood Free Manila, and more. Since the first events in 2012-2014 in Thailand, ClimateCafés have evolved in content but kept their initial aim: find and share solutions for environmental challenges in cities. The most recent focus of environmental challenge is climate change adaptation.

Examples of challenges that have been addressed in previous ClimateCafés are flooding, drought, heat stress, (lack of) nature-based solutions, deforestation, salination, floating urbanization, water quality, subsidence, and waste management. These challenges are always related to a specific geographical location within an urbanized area. Within the period of 2012-2019, a total of 25 events took place mostly in Europe and Asia and single ones in South America and Africa (Fig. 1). ClimateCafés integrate knowledge of different local and international actors who are interested in climate change adaptation by using the quadruple helix approach. Furthermore, ClimateCafés encourage participants from different backgrounds such as educational sector, gender, and nationality to participate. There is a strong emphasis on inclusion for everyone who is interested in climate change adaptation because "We share challenges, let's share solutions." The main target groups are students and (young) professionals who feel the urge to work on climate change adaptation in cities.

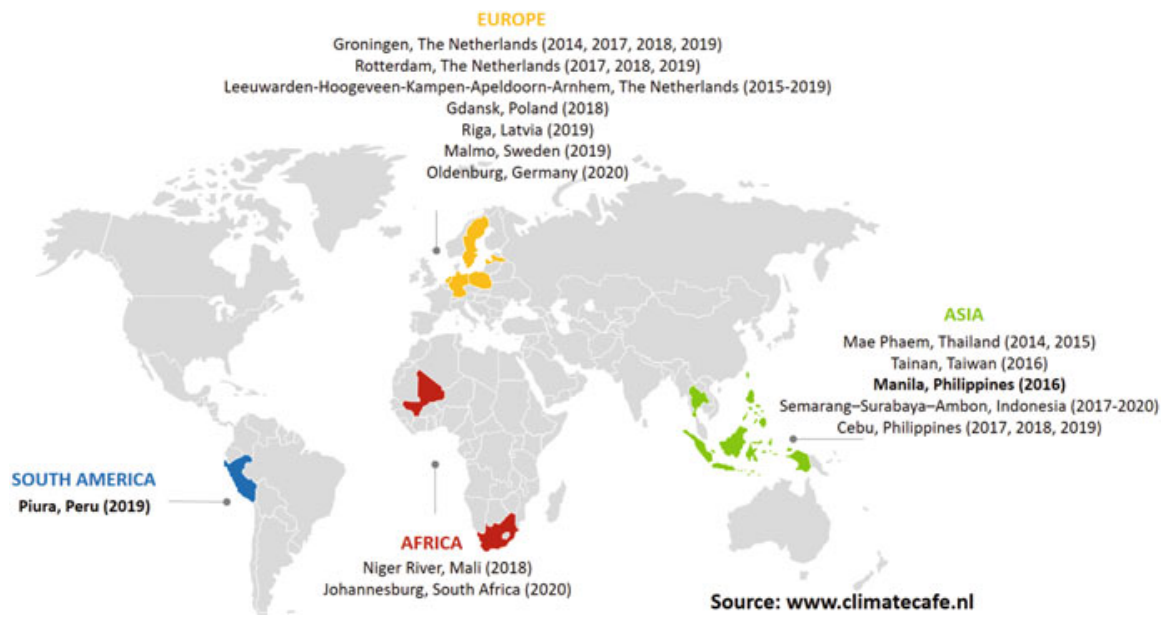

Fig. 1 ClimateCafés arranged worldwide in the period of 2012-2019 (Boogaard et al. 2020) 
At the end of previous ClimateCafés, participants had a change to present their ideas to a high-level audience during conferences. This increases the impact of their work, the exposure of ClimateCafé as a method, and the visibility of youth involvement in climate change adaptation. ClimateCafés are events which can have different specific objectives, depending on the issue which is being addressed. However, every ClimateCafé has similar objectives as well, such as listed below.

Examples of Objectives of Previous ClimateCafés

- To raise awareness about climate change adaptation by action

- To teach and use innovative methods and technologies

- To perform "climate stress tests" in a certain area answering questions about the origin and location and coming up with solutions to problems (such as flooding)

- To create concrete action/tangible results (e.g., a map with problem areas and solutions as co-production with stakeholders)

- To work in interdisciplinary and international teams

During a ClimateCafé, participants go out in the field to collect data, analyze data, and participate in workshops. Data collection, analysis, and workshop content are dependent on the specific challenge of the area (e.g., flooding, heat, pollution). The type of data collection, analysis, and workshops is dependent on the expertise of coordinators and involved stakeholders. The data which is collected during ClimateCafés is also used for scientific publications (Boogaard et al. 2020).

Different tools for data collection have been used during the previous ClimateCafés. Tools are either "quick and dirty," "high-tech," or "innovative" (or a combination). An example of such a tool is "ClimateScan," an open-source platform displayed at climatescan.org and affiliated with ClimateCafés since the beginning. This tool is used to share climate adaptation solutions effectively worldwide (Tipping et al. 2015; Boogaard et al. 2017). With the combination of local data and worldwide solutions, participants are inspired to make knowledge-based decisions on effective solutions in workshops.

The workshops during previous ClimateCafés have different forms. Workshops are either aimed at sharing knowledge through presentations or visits, at using existing data, or at creating new ideas in design workshop. An example of sharing knowledge is visits to water authorities and involvement of scientists who share their knowledge. Using existing data workshops are, for instance, climate scenarios and using the Sustainable Development Goals (SDGs) in a regional context (UN Sustainable Development Goals 2019).

The specific examples of activities within each ClimateCafé vary for each location. Therefore, every ClimateCafé has a different context-specific objectives and a local impact, corresponding with the needs and wishes of the collaborating parties. 


\section{Uncertainty Framework for ClimateCafés}

ClimateCafé content can be linked to the three different types of uncertainty (epistemic, ontic, and ambiguity). Therefore, this has been used as a framework to categorize the content of learning by doing in ClimateCafés (see Fig. 2). According to this framework, a ClimateCafé consists of four blocks: (1) assessing the current state by fieldwork (e.g., measuring water quality/quantity, heat stress) to address epistemic uncertainty, (2) linking the current state to future challenges to address ontic uncertainty, (3) collecting multiple perspectives by stakeholder engagement and co-production to address ambiguity, and (4) combining this knowledge to inspire ClimateCafé members toward innovating solutions, action and tangible results.

For each block, there are a wide variety of methods available. Depending on the chosen challenge, the availability of experts, and the time, methods can be picked. Corresponding blocks have modular work packages/workshops. Table 1 presents some examples of workshops to address the questions of the different blocks.

\section{Two Case Studies: Manila and Piura}

To get an idea of the different activities in ClimateCafés, two of these events in the Philippines and Peru are described in the next paragraphs. These two ClimateCafés have been chosen because (1) it shows the progress between early ClimateCafés and more recent ones, because (2) it demonstrates the difference between a "double" ClimateCafé (two successions) and a "single" ClimateCafé, (3) because it

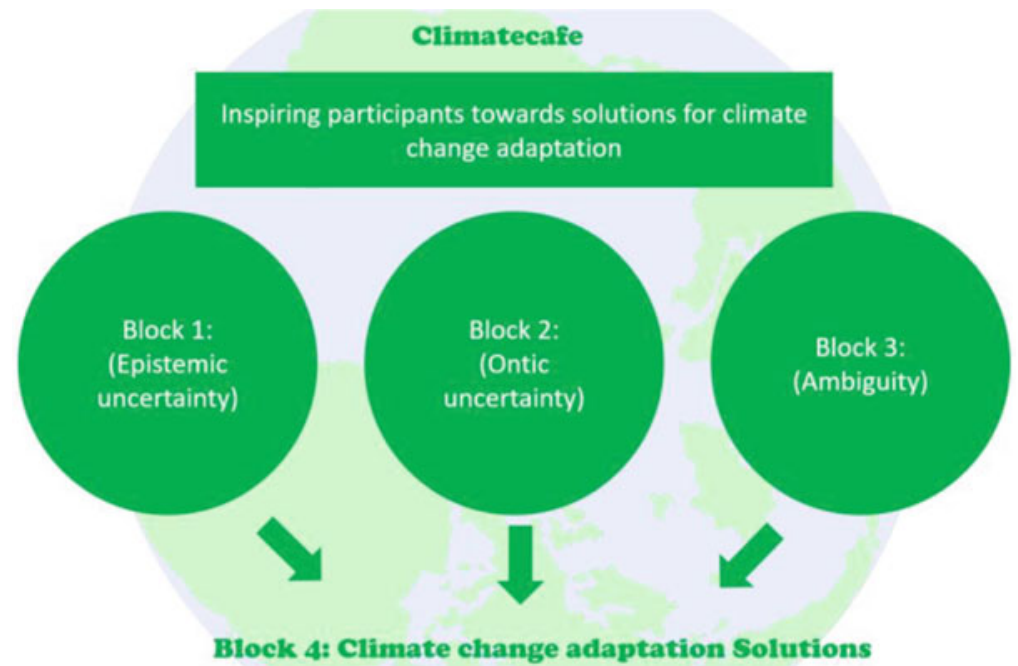

Fig. 2 Uncertainty blocks ClimateCafé 
Table 1 ClimateCafé blocks framework

\begin{tabular}{|c|c|c|c|}
\hline \multicolumn{4}{|l|}{ ClimateCafé Blocks } \\
\hline $\begin{array}{l}\text { Block } 1 \\
\text { Epistemic uncertainty: } \\
\text { addressing the current } \\
\text { state }\end{array}$ & $\begin{array}{l}\text { Block } 2 \\
\text { Ontic } \\
\text { uncertainty: } \\
\text { addressing the } \\
\text { future state }\end{array}$ & $\begin{array}{l}\text { Block } 3 \\
\text { Ambiguity: } \\
\text { addressing } \\
\text { multiple } \\
\text { perspectives }\end{array}$ & $\begin{array}{l}\text { Block } 4 \\
\text { Decision-making: } \\
\text { addressing solutions for } \\
\text { climate change adaptation }\end{array}$ \\
\hline $\begin{array}{l}\text { Activity: } \\
\text { Data collection and } \\
\text { fieldwork on location } \\
\text { relevant parameters } \\
\text { "What is the current } \\
\text { situation?" }\end{array}$ & $\begin{array}{l}\text { Activity: } \\
\text { Scenario and } \\
\text { vision creation } \\
\text { "How might the } \\
\text { future look } \\
\text { like?" }\end{array}$ & $\begin{array}{l}\text { Activity: } \\
\text { Stakeholder } \\
\text { analysis and } \\
\text { involvement } \\
\text { "Who is involved } \\
\text { and what are their } \\
\text { perspectives?" }\end{array}$ & $\begin{array}{l}\text { Activity: } \\
\text { Create concrete handling } \\
\text { perspective } \\
\text { "What concrete actions } \\
\text { can we propose?" }\end{array}$ \\
\hline $\begin{array}{l}\text { Workshop examples: } \\
\text { • Measuring water/ } \\
\text { soil quality parameters } \\
\text { • Measuring water } \\
\text { quantity parameters } \\
\text { - Heat stress } \\
\text { measuring }\end{array}$ & $\begin{array}{l}\text { Workshop } \\
\text { examples: } \\
\text { • Adaptation } \\
\text { pathways } \\
\text { • Vision } \\
\text { creation } \\
\text { • Scenario } \\
\text { creation } \\
\text { • System } \\
\text { analysis } \\
\text { • Sustainable } \\
\text { Development } \\
\text { Goals analysis }\end{array}$ & $\begin{array}{l}\text { Workshop } \\
\text { examples: } \\
\text { • Interviews } \\
\text { • Mind maps } \\
\text { • Role-playing } \\
\text { games }\end{array}$ & $\begin{array}{l}\text { Workshop examples: } \\
\text { • Mini-symposium } \\
\text { • Presenting at high- } \\
\text { level conference }\end{array}$ \\
\hline
\end{tabular}

demonstrates the difference between "quick and dirty" tools and "high-tech" tools, and (4) because one of the participants of the early ClimateCafé became the coorganizer of the more recent ClimateCafé.

Early ClimateCafés in the Philippines focused on the city of Manila in two successions. ClimateCafés were held in Manila in the year 2016, where several organizations from the Philippines and the Netherlands joined forces to rehabilitate rivers and introduce new innovations for water quality monitoring and waste collection. The first succession took place in April 2016 and the second in October 2016. The more recent ClimateCafé in Peru focused on the city of Piura during one event in October 2019, in which partners from the Peruvian government, the Dutch government, companies, and universities joint efforts to address flooding issues, water quality assessment, and heat stress in one of the urban areas of Piura next to the Piura River. This paragraph provides an overview of the challenges that have been addressed, the partners and partnerships involved, the participants, and the tools that were used during both ClimateCafés.

\section{Challenges in Manila and Piura}

In coastal and low-lying vulnerable delta cities, such as Metropolitan Manila, there has been an increase in vulnerability of urban flooding and water quality problems. 


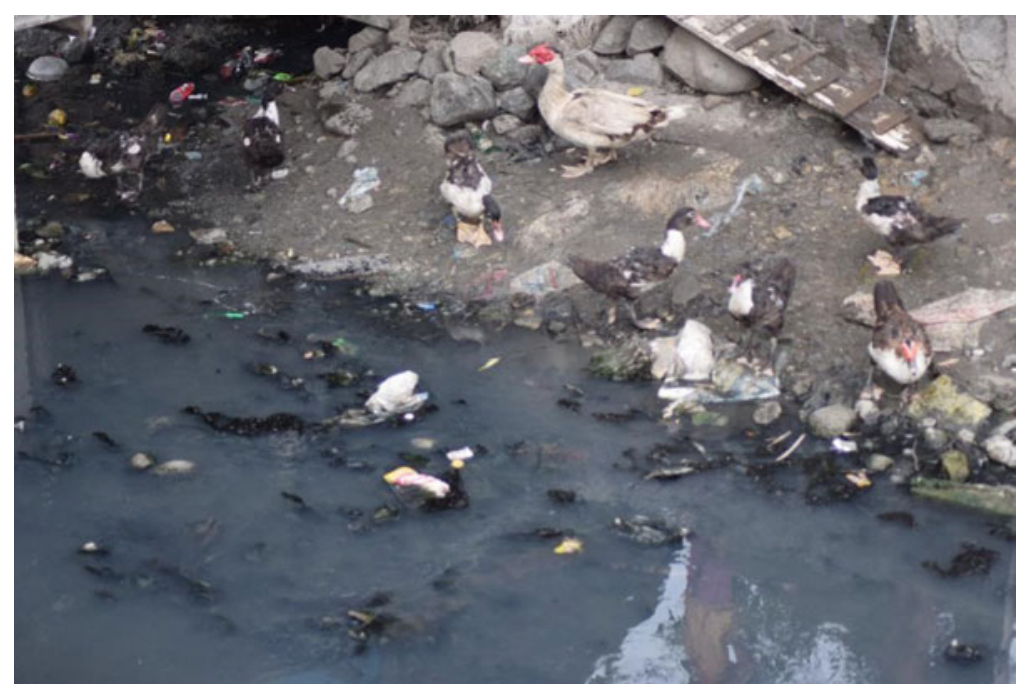

Fig. 3 Degradation of waterways in Manila in 2016: black water used by livestock and people

New approaches address the current and future effects of climate change and increase urban quality, reduce vulnerability, and increase water quality. Fresh water systems are rapidly changing, and water quality is deteriorating as a result of climate change and increasing fallout from human activities that accelerate physical and chemical changes in water systems around the globe (Lima et al. 2019). Mega cities, such as metropolitan Manila, typically face rapid expansion and uncontrolled urban sprawl, resulting in the lack of infrastructure and wastewater treatment facilities. Urbanization also increases the variety and quantities of pollutants found in downstream receiving waters (Boogaard et al. 2016). An example of this is the large amount of solid waste and the difficulties of waste management in Mega cities such as Manila. Metropolitan Manila is an example of a metropolis where rapid urban growth resulted in a river system that is biologically dead, as depicted in Fig. 3 .

In non-coastal cities, such as the city of Piura in Peru, similar challenges are found. Extreme events such as heavy flooding in 2017 caused severe damage in various parts of Peru, one of them being in the city of Piura (https://www. theguardian.com/world $/ 2017 / \mathrm{mar} / 17 /$ peru-floods-ocean-climate-change; https:// www.pri.org/stories/2017-09-14/houston-flooded-there-was-piura-peru). Piura is situated in the north of Peru and has almost half a million inhabitants. A river, the Piura River, crosses the city, originates in the Andes, and contains several dams to regulate the river flow. Next to flooding, the region faces challenges in water scarcity and land degradation (http://aquasec.org/wp-content/uploads/2015/05/ PiuraFactSheet-English-1-2.pdf). These challenges, due to El Niño effects, are expected to increase in the future, making adaptation crucial (http://www.fao.org/ 3/a1598e/a1598e12.htm). Episodes of drought and high temperatures increase which, together with increase pavement, makes the city hotter. 
The quality of the river system in Metro Manila seems to be a status quo, which cannot be changed. However, if we look at other similar cases in Europe such as the Amsterdam canals with UNESCO world heritage status, we see that these canals were not suitable for swimming decades ago (RIVM 2007), but in last years about 2500 swimmers participated in the Amsterdam City Swim in the Amsterdam canals to swim a 2000-m course through the city center. Therefore, the specific objective of ClimateCafé Manila was to rehabilitate the river by addressing water quality and solid waste in the Pasig and Pateros River. During the two successions of the ClimateCafés, the first focused on problem framing, data gathering, and ideating, and the second focused on more data collection and implementation of ideas (Delta Talent 2016).

The extreme events in Piura are presumably aggregated by climate change. Parts of the city have been inundated before. The focus area is the urbanized neighborhood of Los Cocos in Piura, which was severely inundated in 2017 by the Piura River. The "Los Ejidos" dam upstream of the river regulates the flow of the Piura River. Therefore, the specific objective of ClimateCafé Piura was to address the challenges and come up with solutions for the Piura River flooding in the light of El Niño effects and climate change in the area of Los Cocos.

\section{Partners, Partnerships, and Parties in Manila and Piura}

The Manila ClimateCafé initiative officially started with the signing of a Memorandum of Agreement (MOA) in the presence of the mayors of the different city districts within Manila (Makati City, Pasig City, Taguig City, and Pateros), the Rotary Club of Makati Pasong Tamo, the Department of Interior and Local Government, The Netherlands Embassy, Rotterdam University of Applied Sciences, Groningen University of Applied Sciences, and consultancy firm Tauw and WaterWegen (see Table 2). The MOA embodies the commitment and support to rehabilitate and sustain the integrity of the decaying and heavily polluted Pateros River for the sake of ecological balance.

ClimateCafé Piura was organized in collaboration between the (Applied) universities from the Netherlands and Peru, national and regional water authorities, companies with international experience, and coordinators of the Young Leaders Program of the Global Center on Adaptation (see Table 2). The ClimateCafé initiative is a side event of the BlueDeal agreement between the governments of Peru and the Netherlands to share knowledge on water management and supported stakeholder interactions between generations. Partners within this are the Dutch Water Authorities (DWA) and the national water authority of Peru (ANA). The Hanze University of Applied Sciences (HUAS), Groningen, and the Universidad de Piura (UDEP) worked together, and UDEP hosted the event in Piura. As a part of UDEP, the Vida Universitaria provided a link with civic society and promoted student applications. The INDYMO company provided expertise and tools for water quality measurements and coordination of the ClimateCafé.

This demonstrates that ClimateCafé Manila involved public stakeholders (mayors and barangay captains that signed the MOA), private partners (Tauw Group and 
Table 2 ClimateCafé Manila and Peru main outcomes

\begin{tabular}{|c|c|c|}
\hline & $\begin{array}{l}\text { ClimateCafé Manila (April and } \\
\text { October 2016) }\end{array}$ & ClimateCafé Peru (October 2019) \\
\hline $\begin{array}{l}\text { Global } \\
\text { challenge }\end{array}$ & $\begin{array}{l}\text { Resilient cities and climate change } \\
\text { adaptation }\end{array}$ & $\begin{array}{l}\text { Resilient cities and climate change } \\
\text { adaptation }\end{array}$ \\
\hline Local focus & $\begin{array}{l}\text { River rehabilitation Pasig/Pateros } \\
\text { River (water quality and solid waste) }\end{array}$ & $\begin{array}{l}\text { Climate change adaptation Los Cocos } \\
\text { area Piura (flooding, heat stress, and } \\
\text { water quality Piura River) }\end{array}$ \\
\hline Objective & $\begin{array}{l}\text { To rehabilitate the river by addressing } \\
\text { water quality and urban waste in the } \\
\text { Pasig and Pateros River }\end{array}$ & $\begin{array}{l}\text { To address the challenges and come up } \\
\text { with solutions for the Piura River } \\
\text { flooding in the light of El Niño effects } \\
\text { and climate change in the area of Los } \\
\text { Cocos }\end{array}$ \\
\hline $\begin{array}{l}\text { Academic } \\
\text { partners }\end{array}$ & $\begin{array}{l}\text { Hanze University of Applied Sciences } \\
\text { (HUAS), Groningen, } \\
\text { Rotterdam university of applied } \\
\text { sciences (RUAS), University of the } \\
\text { Philippines }\end{array}$ & $\begin{array}{l}\text { Hanze University of Applied Sciences } \\
\text { (HUAS), Groningen, } \\
\text { University of Piura (UDEP) }\end{array}$ \\
\hline $\begin{array}{l}\text { Public } \\
\text { partners }\end{array}$ & $\begin{array}{l}\text { National Ministry, mayors of Makati } \\
\text { City, Pasig City, Taguig City, and } \\
\text { Pateros, Department of Interior and } \\
\text { Local Government, The Netherlands } \\
\text { Embassy } \\
\text { PRRC (Pasig River Rehabilitation } \\
\text { Committee) }\end{array}$ & $\begin{array}{l}\text { Dutch Water Authorities (DWA), } \\
\text { Autoridad Nacional del Agua Peru } \\
\text { (ANA) } \\
\text { Young Leaders Programme of the } \\
\text { Global Center on Adaptation (YLP, } \\
\text { GCA) }\end{array}$ \\
\hline $\begin{array}{l}\text { Private } \\
\text { partners }\end{array}$ & $\begin{array}{l}\text { Tauw Group } \\
\text { WaterWegen }\end{array}$ & Indymo \\
\hline $\begin{array}{l}\text { Civic } \\
\text { society }\end{array}$ & $\begin{array}{l}\text { The Rotary Club of Makati Pasong } \\
\text { Tamo }\end{array}$ & Vida Universitaria \\
\hline $\begin{array}{l}\text { Tools } \\
\text { applied }\end{array}$ & $\begin{array}{l}\text { To collect, distribute, and share } \\
\text { knowledge, the open-access, web- } \\
\text { based http://www.Climatescan.org } \\
\text { adaptation tool was applied } \\
\text { Test strips and phones were used for } \\
\text { water quality assessment (temp., EC, } \\
\text { pH, iron, P, N, Cl) } \\
\text { Observations } \\
\text { Design workshops } \\
\text { Building workshops }\end{array}$ & $\begin{array}{l}\text { To collect, distribute, and share } \\
\text { knowledge, the open-access, web- } \\
\text { based http://www.Climatescan.org } \\
\text { To map water quality, water drones } \\
\text { were used } \\
\text { Heat stress data was gathered and } \\
\text { analyzed by the use of sensors in a bike } \\
\text { Future workshop } \\
\text { Observation techniques }\end{array}$ \\
\hline Participants & $\begin{array}{l}\text { Dutch and Philippine students from } \\
\text { HUAS, RUAS, and University of the } \\
\text { Philippines } \\
\text { Coordination by Dutch (HUAS, } \\
\text { TAUW, WaterWegen) and The } \\
\text { Philippines/International (the Rotary } \\
\text { Club) }\end{array}$ & $\begin{array}{l}\text { Peruvian students from UDEP and } \\
\text { UNP with Dutch coordinators } \\
\text { (INDYMO, HUAS), Peruvian } \\
\text { organizations (UDEP and Vida } \\
\text { Universitaria), and international } \\
\text { organization (GCA) }\end{array}$ \\
\hline Disciplines & $\begin{array}{l}\text { Civil engineering, water management, } \\
\text { urban planning }\end{array}$ & $\begin{array}{l}\text { Civil engineering, economics, } \\
\text { industrial engineering, law, } \\
\text { environmental engineering, } \\
\text { mechanical engineering, water } \\
\text { management }\end{array}$ \\
\hline
\end{tabular}


WaterWegen), knowledge institutes (Hanze University of Applied Sciences (HUAS), Groningen, Rotterdam University of Applied Sciences (RUAS), and University of the Philippines), and civic society (the Rotary Club). ClimateCafé Piura similarly included governmental partners (Dutch and Peruvian water authorities), universities (HUAS and UDEP), companies (INDYMO), and links with civic society (Vida Universitaria) and focused on youth and students from Piura.

\section{Participants and Tools Applied in Manila and Piura}

In the two successions of ClimateCafé Manila, participants involved Dutch and Philippine students from HUAS and the University of the Philippines with mainly Dutch organizers. Students from civil engineering, water management, and urban planning collaborated in an interdisciplinary and multidisciplinary setting, involving with several stakeholders and civic society. Different research methods are applied such as observations, ClimateScan, water quality monitoring, surveys, design workshops, and building workshops.

During ClimateCafé Piura, participants involved Peruvian students from UDEP and from the national university of Piura (UNP) with Dutch and Peruvian coordinators. Students from several disciplines such as civil engineering, economics, industrial engineering, law, environmental engineering, and mechanical engineering combined forces in this interdisciplinary setting. Participants interacted with several stakeholders and civic society by visits and interviews. Subsequently, observation, excursions, workshops, water quality measurements, and heat stress measurements provided data and inspiration for the design workshop.

\section{Two ClimateCafés: Main Outcomes}

ClimateCafé Manila and Piura addressed water quality and water quantity challenges, in relation with resilient cities and climate change adaptation. While ClimateCafé manila focused on the issues of the Pasig and Pateros River, ClimateCafé Piura focused on one urbanized area. ClimateCafé Manila contained two editions, while Piura has been a single edition. Both ClimateCafés were first in the area; therefore, both ClimateCafés focused on exploring climate change-related challenges and bringing together different stakeholders. The individual ClimateCafés are summarized in Table 2, and the content is described in detail in the next paragraphs.

\section{Content and Uncertainty}

Epistemic uncertainty has been addressed in both ClimateCafés in several ways. Excursions and observations of the focus areas provided an introduction for the ClimateCafé. Field work in data collection contributed to more in-depth knowledge and relevant data of the area. In Manila, this has been done by measuring river velocity and quality with tools such as test strips (water quality parameters as temp., 
electrical conductivity $(\mathrm{EC}), \mathrm{pH}$, iron, phosphate $(\mathrm{P})$ nitrate $(\mathrm{N})$, chlorine $(\mathrm{Cl}))$ and measuring discharge of the river by small floating objects. In Piura, data has been collected on river quality with an aquatic drone (Lima et al. 2019), and climate data has been collected with mobile (bike) sensors. Furthermore, ClimateCafé Piura collected observational data with aquatic drones (Lima et al. 2019) and ClimateScan (Boogaard et al. 2020), determining water quality parameters and possible implementations for water quality improvement (see also Tools in Table 2). Subsequently, both ClimateCafés used the ClimateScan app to find existing adaptation measures.

Ontic uncertainty has been addressed in ClimateCafé Piura by a future workshop. In this workshop different scenarios were introduced. Both quantitative (in the form of climate change scenarios such as the Representative Concentration Pathways) and qualitative (such as the Shared Socioeconomic Pathways) were presented as possible futures to answer the question "what could happen." With this information, a switch has been made to the Sustainable Development Goals (SDGs) as a global answer to the question "what should happen." A cognitive map of the SDGs was made to understand how different goals are related to encourage system thinking. Next to this, the participants made a regional vision with the visualization technique of mood boards to define a desired future for Piura in 2030.

Ambiguity has been addressed in both ClimateCafés by interviewing residents about their perceptions on their neighborhood, related to the addressed challenges. In ClimateCafé Manila perceptions about the pollution of the rivers were conducted by semi-structured interviews. In ClimateCafé Piura, perceptions, about, e.g., heat and inundation hinderance of the past, present, and worry about the future, have been conducted with structured interviews. Furthermore, ambiguity has been addressed by visits to local authorities and conversations with stakeholders who address the specific challenges. During the ClimateCafé in Manila, this was done by visiting barangay (local municipalities within Manila) offices. In ClimateCafé Piura, this has been done by visiting the national water authority.

Both ClimateCafés used design workshops to define ideas and make a decision on suitable solutions, related to their specific challenge. Next to this, both ClimateCafés gave the opportunity to present final ideas during a symposium. In Manila, the design workshop made use of brainstorming and prioritization of ideas. Specific prioritization was given to ideas which were relatively "simple" to implement, referring to low costs and minimum required behavioral change. The Piura ClimateCafé made use of the climatescan.org app for inspirational purposes and presented multiple ideas on a more theoretical level and defined a buffer zone in case of extreme events. An addition of ClimateCafé Manila was the actual implementation of the idea in a building workshop.

Both ClimateCafés addressed epistemic uncertainty and ambiguity. Ontic uncertainty has only been addressed in ClimateCafé Piura, and implementation of ideas was only done in ClimateCafé Manila. Table 3 provides a summarized content of both ClimateCafés. 
Table 3 Method and Activities of ClimateCafés in the Philippines and Peru

\begin{tabular}{|c|c|c|c|c|}
\hline \multirow[b]{2}{*}{ Block } & \multicolumn{2}{|l|}{ Manila } & \multicolumn{2}{|l|}{ Piura } \\
\hline & Activities and aim & Method & Activities and aim & Method \\
\hline \multirow[t]{5}{*}{$\begin{array}{l}\text { Block 1 } \\
\text { Epistemic } \\
\text { Uncertainty } \\
\text { Addressing } \\
\text { the current } \\
\text { state }\end{array}$} & $\begin{array}{l}\text { Excursion to } \\
\text { Pateros } \\
\text { neighborhood to } \\
\text { observe river } \\
\text { quality }\end{array}$ & Observation & $\begin{array}{l}\text { Excursion to "Los } \\
\text { Ejidos" dam and } \\
\text { reservoir to } \\
\text { understand } \\
\text { hydrology of the } \\
\text { Piura River water } \\
\text { system }\end{array}$ & $\begin{array}{l}\text { Observation and } \\
\text { presentations }\end{array}$ \\
\hline & $\begin{array}{l}\text { River velocity } \\
\text { measurements } \\
\text { Pateros River on } \\
\text { one specific } \\
\text { location }\end{array}$ & $\begin{array}{l}\text { "Floating object } \\
\text { test in river" and } \\
\text { time for } \\
\text { indication of } \\
\text { river water } \\
\text { velocity and } \\
\text { discharge at } \\
\text { several locations }\end{array}$ & $\begin{array}{l}\text { Water quality } \\
\text { monitoring in } \\
\text { lLos Ejidos } \\
\text { reservoir and in } \\
\text { Rio Piura to: } \\
\text { 1. Baseline of } \\
\text { water quality } \\
\text { parameters (e.g., } \\
\text { electrical } \\
\text { conductivity, } \\
\text { chlorophyll, } \\
\text { dissolved oxygen, } \\
\text { temperature) in } \\
\text { the Reservoir } \\
\text { upstream of "ILos } \\
\text { Ejidos" and in the } \\
\text { Piura River } \\
\text { (downstream of } \\
\text { dam, near the city } \\
\text { center) } \\
\text { 2. Bathymetry } \\
\text { map of lLos } \\
\text { Ejidos basin }\end{array}$ & $\begin{array}{l}\text { Aquatic drones } \\
\text { INDYMO }\end{array}$ \\
\hline & $\begin{array}{l}\text { Water quality } \\
\text { measuring Pasig } \\
\text { River to gain } \\
\text { insights into the } \\
\text { spatial variability } \\
\text { of water quality } \\
\text { (with apps) }\end{array}$ & $\begin{array}{l}\text { Test strips } \\
\text { (temp., } \mathrm{EC}, \mathrm{pH} \text {, } \\
\text { iron, } \mathrm{P}, \mathrm{N}, \mathrm{Cl} \text { ) }\end{array}$ & $\begin{array}{l}\text { Heat stress } \\
\text { measuring in Los } \\
\text { Cocos } \\
\text { neighborhood }\end{array}$ & $\begin{array}{l}\text { Temperature, } \\
\text { radiation, wind } \\
\text { speed sensors in } \\
\text { a mobile sensor } \\
\text { on a bike }\end{array}$ \\
\hline & & & $\begin{array}{l}\text { Storytelling: } \\
\text { observations in } \\
\text { Los Cocos } \\
\text { neighborhood }\end{array}$ & $\begin{array}{l}\text { Predefined } \\
\text { questionnaires } \\
\text { with } \\
\text { ODK collect } \\
\text { app and } \\
\text { mapping } \\
\text { solutions on } \\
\text { climatescan.org }\end{array}$ \\
\hline & $\begin{array}{l}\text { Mapping existing } \\
\text { adaptation } \\
\text { measures }\end{array}$ & Climatescan.org & $\begin{array}{l}\text { Mapping existing } \\
\text { adaptation } \\
\text { measures }\end{array}$ & Climatescan.org \\
\hline
\end{tabular}


Table 3 (continued)

\begin{tabular}{|c|c|c|c|c|}
\hline \multirow[b]{2}{*}{ Block } & \multicolumn{2}{|l|}{ Manila } & \multicolumn{2}{|l|}{ Piura } \\
\hline & Activities and aim & Method & Activities and aim & Method \\
\hline $\begin{array}{l}\text { Block } 2 \\
\text { Ontic } \\
\text { uncertainty } \\
\text { Addressing } \\
\text { the future } \\
\text { state }\end{array}$ & & & $\begin{array}{l}\text { Future workshop } \\
\text { to introduce } \\
\text { climate change } \\
\text { projections, } \\
\text { socioeconomic } \\
\text { scenarios, and the } \\
\text { Sustainable } \\
\text { Development } \\
\text { Goals and to } \\
\text { create a system } \\
\text { analysis map of } \\
\text { the SDGs and a } \\
\text { vision of "Piura in } \\
\text { 2030" }\end{array}$ & $\begin{array}{l}\text { Cognitive } \\
\text { mapping } \\
\text { Bbrainstorming } \\
\text { and visualizing } \\
\text { mood boards }\end{array}$ \\
\hline \multirow[t]{2}{*}{$\begin{array}{l}\text { Block } 3 \\
\text { Ambiguity } \\
\text { Addressing } \\
\text { multiple } \\
\text { perspectives }\end{array}$} & $\begin{array}{l}\text { Storytelling: } \\
\text { interviewing } \\
\text { residents living } \\
\text { and working near } \\
\text { the river }\end{array}$ & $\begin{array}{l}\text { Semi-structured } \\
\text { interviews }\end{array}$ & $\begin{array}{l}\text { Storytelling: } \\
\text { interview } \\
\text { residents of Los } \\
\text { Cocos }\end{array}$ & $\begin{array}{l}\text { Predefined } \\
\text { questionnaires } \\
\text { with } \\
\text { ODK collect } \\
\text { app }\end{array}$ \\
\hline & $\begin{array}{l}\text { Visit office of } \\
\text { West Rembo } \\
\text { bBarangay } \\
\text { oOffice and } \\
\text { Pateros } \\
\text { Municipal Hall } \\
\text { for stakeholder } \\
\text { perceptions and } \\
\text { engagement }\end{array}$ & & $\begin{array}{l}\text { Visit office of } \\
\text { national water } \\
\text { authority for } \\
\text { stakeholder } \\
\text { perceptions and } \\
\text { engagement }\end{array}$ & \\
\hline \multirow{3}{*}{$\begin{array}{l}\text { Block } 4 \\
\text { Decision- } \\
\text { making } \\
\text { Addressing } \\
\text { solutions } \\
\text { for climate } \\
\text { change } \\
\text { adaptation }\end{array}$} & $\begin{array}{l}\text { Design workshop } \\
\text { for waste } \\
\text { management to } \\
\text { prevent pollution } \\
\text { of solid waste }\end{array}$ & $\begin{array}{l}\text { Brainstorming, } \\
\text { prioritizing }\end{array}$ & $\begin{array}{l}\text { Design challenge } \\
\text { for flood } \\
\text { prevention }\end{array}$ & climatescan.org \\
\hline & $\begin{array}{l}\text { Symposium to } \\
\text { disseminate } \\
\text { prioritized idea } \\
\text { for solid waste } \\
\text { pollution } \\
\end{array}$ & & $\begin{array}{l}\text { Mini-symposium } \\
\text { to disseminate } \\
\text { ideas for flood } \\
\text { resilience in the } \\
\text { Los Cocos area }\end{array}$ & \\
\hline & $\begin{array}{l}\text { Building } \\
\text { workshop to } \\
\text { implement } \\
\text { prioritized idea } \\
\text { (the Longganisa) }\end{array}$ & & & \\
\hline
\end{tabular}




\section{ClimateCafés and Generating Ideas}

\section{Epistemic Uncertainty}

Reduction of epistemic uncertainty has been achieved by observations and water quality monitoring during both ClimateCafés and additional mapping of adaptation and waterquality improvement measures. The most essential observations of the Pateros and Pasig River in Manila has been the black water and direct discharge of untreated wastewater, the smell of the water, and the amount of solid waste and water plants in the river (Figs. 4 and 5). This indicated the poor state of the river and visualized the issue of water quality and solid waste.
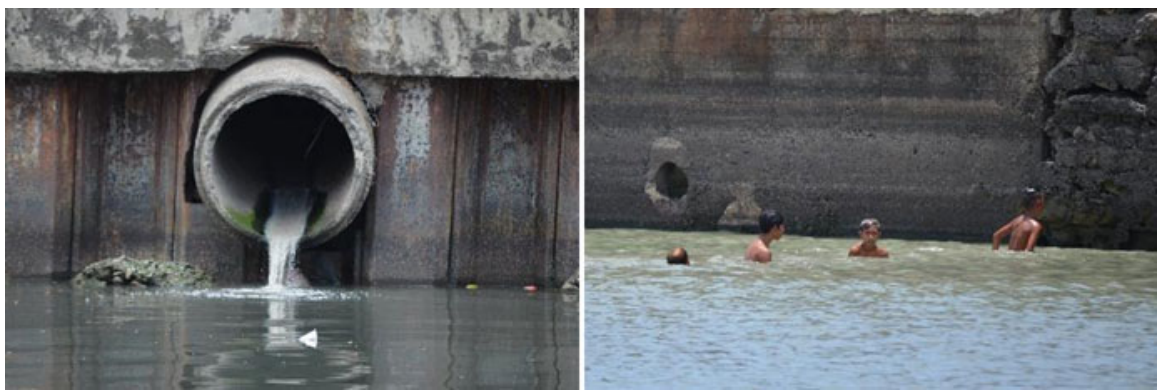

Fig. 4 Direct discharge of untreated wastewater (left) and highly polluted rivers are being used as swimming water near sewer outlet (right) in Manila, Philippines

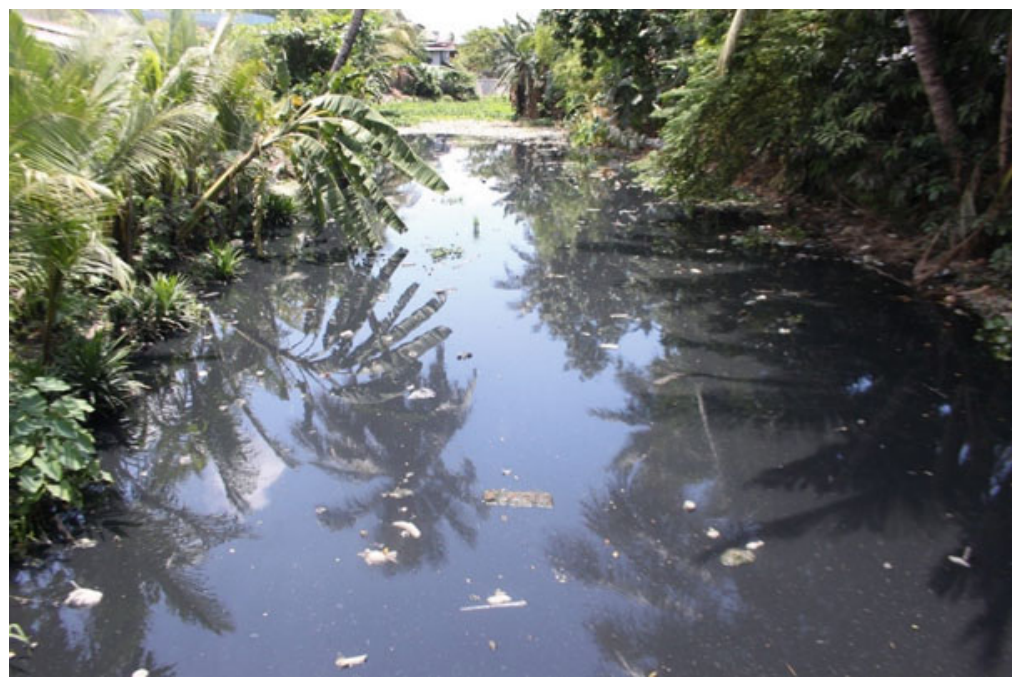

Fig. 5 Black water of the river and clogging by waste and vegetation in Manila, Philippines 

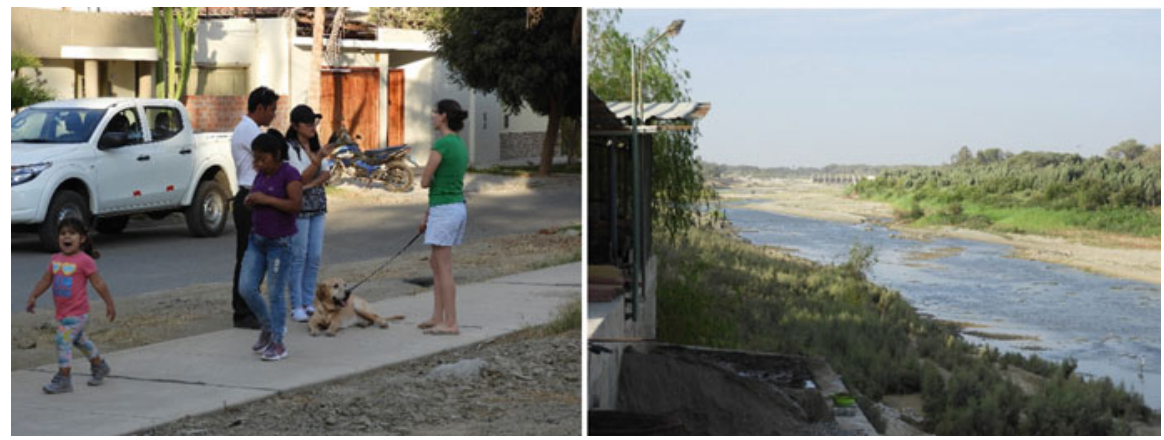

Fig. 6 Interviews in Peru (right) and observation of low-flow Piura River (lower left) (https://m. facebook.com/notes/vida-universitaria-udep/piura-climatecafé-el-proyecto-que-concientiza-sobreel-cambio-climático-en-piura/2527567140861931/)

The most essential observations in the Los Cocos neighborhood of Piura has been the marks that were left during the flooding of 2017 on the houses. Secondly, observations of the basin and current low flow of the Piura River at the Ejidos dam were essential. This indicated the height of the inundation in Los Cocos and the fact that this was an extreme event with a peak river discharge and that the river has a low (managed) flow in general. During fieldtrips semi-structured interviews were taken with residents (Fig. 6).

Researchers and participants of ClimateCafé Manila have taken samples of the water quality at several places along the Pasig River in Manila which have been analyzed using apps on smartphones and being mapped on open source maps. All the results are geolocated on a map, and more results can be uploaded, accessible by anyone with the smartphone application. Tools were applied to monitor water quality to analyze parameters as phosphate, nitrate, iron, electric conductivity, temperature, and $\mathrm{pH}$ (Fig. 7). This first monitoring step "Analyze" (results Fig. 8) was later used for "Action" in order to locate the best locations for the implementation of innovate solutions (workshop "waste management") to address the water pollution.

All information has been mapped on interactive tools as http://www.climatescan. org (Fig. 9). Visualization of the fieldtrips, articles, and presentations in several workshops are used as international knowledge exchange and engagement of stakeholders.

The same mapping was conducted in Piura (Fig. 10). The mapping on the opensource platform ClimateScan illustrates the new data points with photos and videos and additional information from uploaded documents and links to websites.

\section{Ontic Uncertainty}

\section{Cognitive Map of the Sustainable Development Goals}

Cognitive maps of the Sustainable Development Goals (SDGs) demonstrate relations between the individual SDGs and indicate how one SDG cannot be reached 

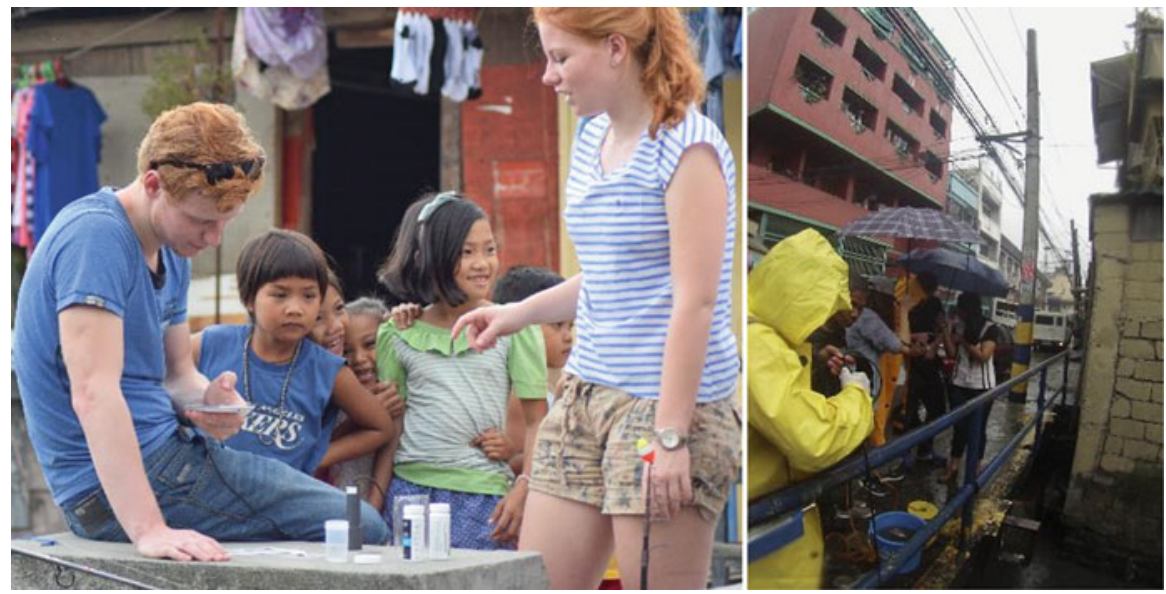

Fig. 7 Tools to map water quality in Manila with telephone and app (left). Knowledge exchange on innovating water quality measurements with sensors from PRRC (Pasig River Rehabilitation Committee) (right)

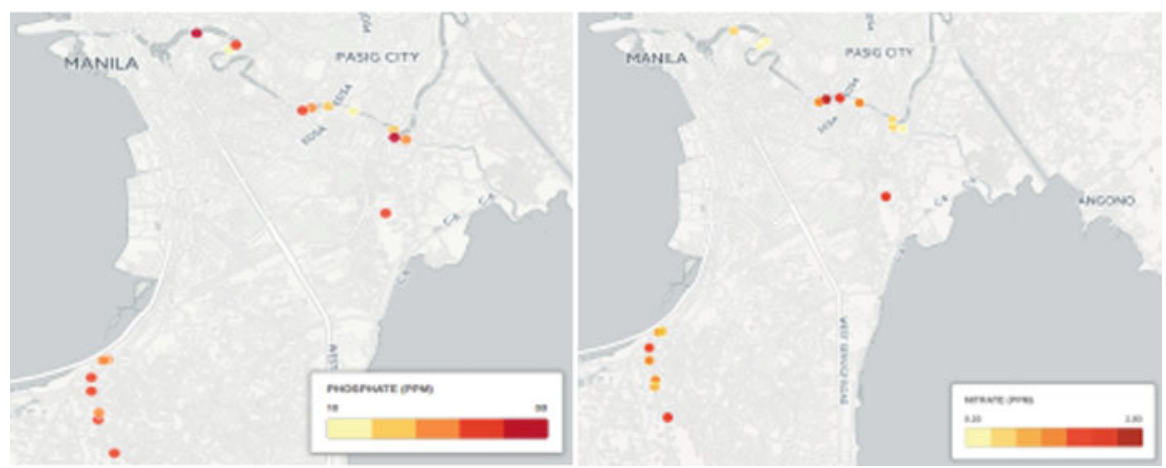

Fig. 8 Results of water quality measurements in Manila (left, phosphate; right, nitrate)

without focusing on SDGs that are related. Zooming out of the addressed issue of flooding in Los Cocos, and switching from current to long-term thinking, this workshop facilitated the discussion of the data and put them in a long-term perspective. All results were discussed in workshops and elucidated the connections with other SDGs (Fig. 11).

\section{Vision 2030}

The mood board of the visions of Piura demonstrate a desired future for the city in 2030. The visions show multiple topics for a liveable city. In the first vison (Fig. 12), streets with vegetation demonstrate how to deal with heat stress. The clean and full river demonstrates how a "normal" flow instead of a "low" flow could enhance the Piura River. Furthermore, related to liveability are solid waste collection initiatives. 


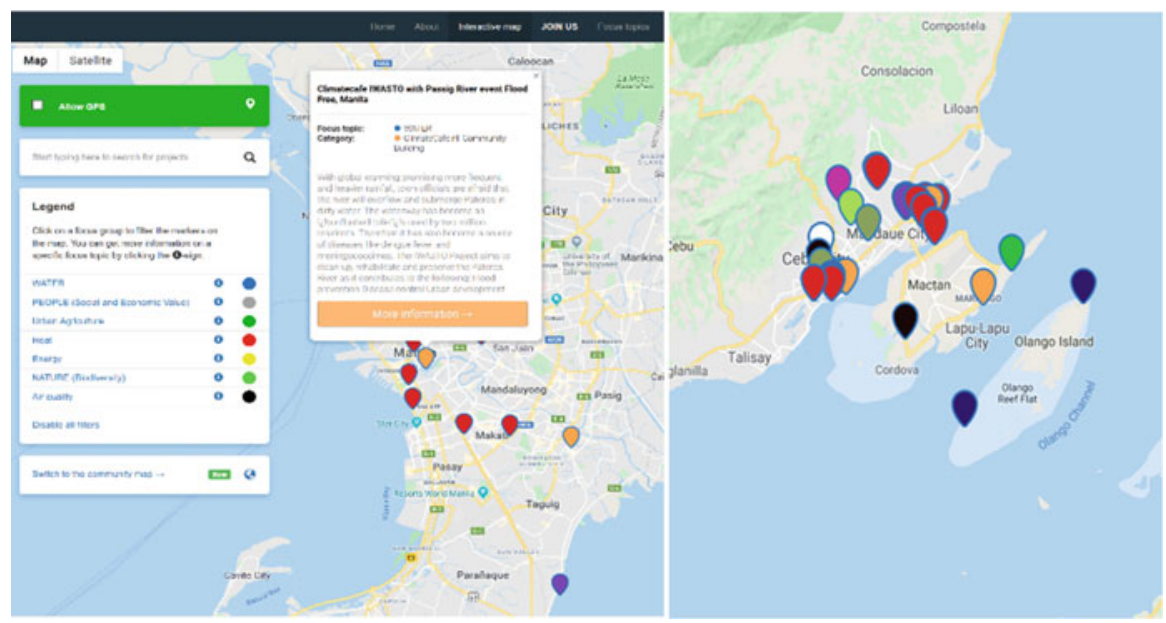

Fig. 9 Results on climatescan.org of ClimateCafé Manila. Indicating problem areas with severe flooding and solutions as floating houses (left). More info https://www.climatescan.nl/projects/343/ detail. ClimateCafé Manila led to ClimateCafés in Cebu (right)
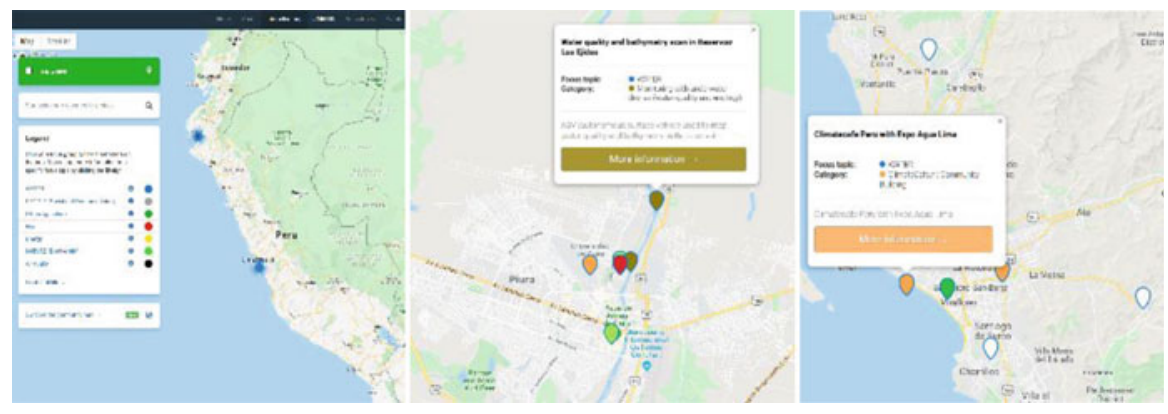

Fig. 10 Results on climatescan.org of ClimateCafé Peru. More info http://www.climatescan.nl/ projects/4382/detail

A solar power field demonstrates that the participants also included climate mitigation and clean energy in their desired future. As a final note, the participants mentioned that the old theater and education can improve awareness of climate adaptation.

The second vision shows similar aspects for a desired future of Piura (Fig. 13). Participants included the wish for more bike lanes and shaded space in their vision. Furthermore, they indicated that a full river could enhance navigation and tourism on the river, and they wanted to include the river to live with the water and to make the river more enjoyable for citizens of Piura. 


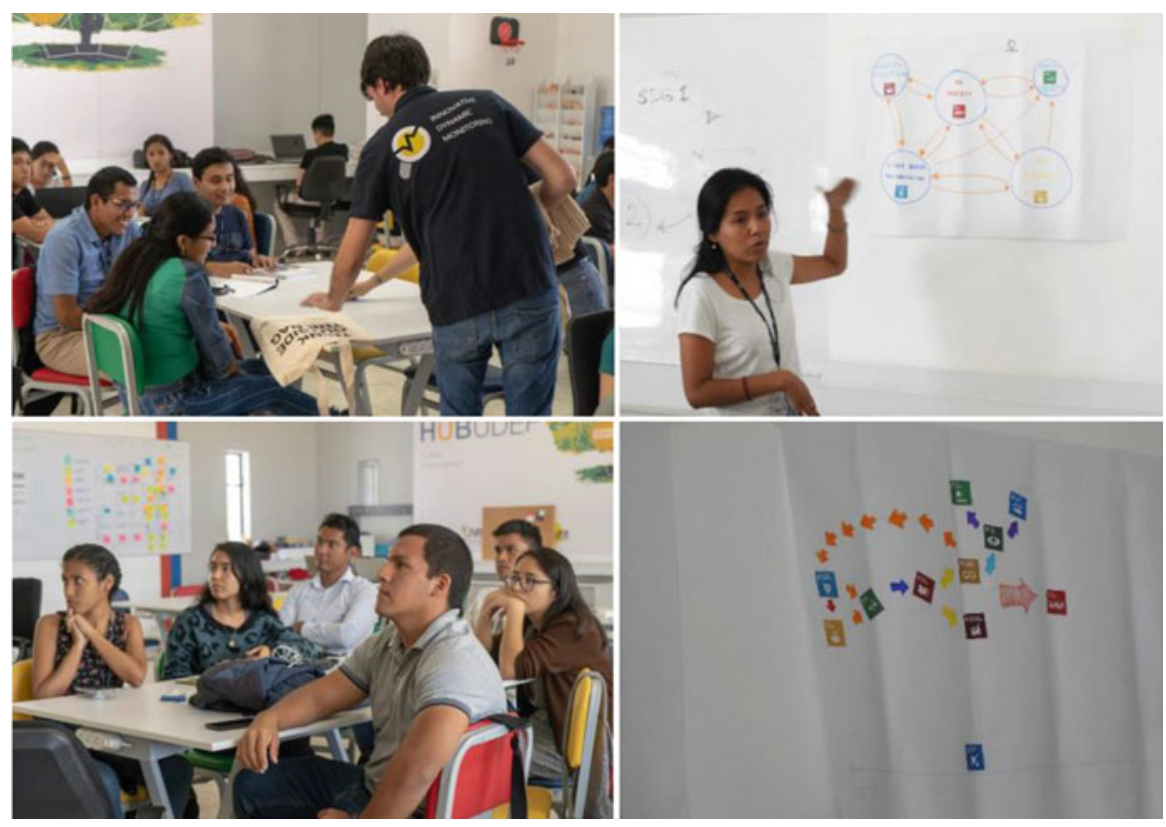

Fig. 11 Discussions in workshops during ClimateCafé Peru with the SDGs

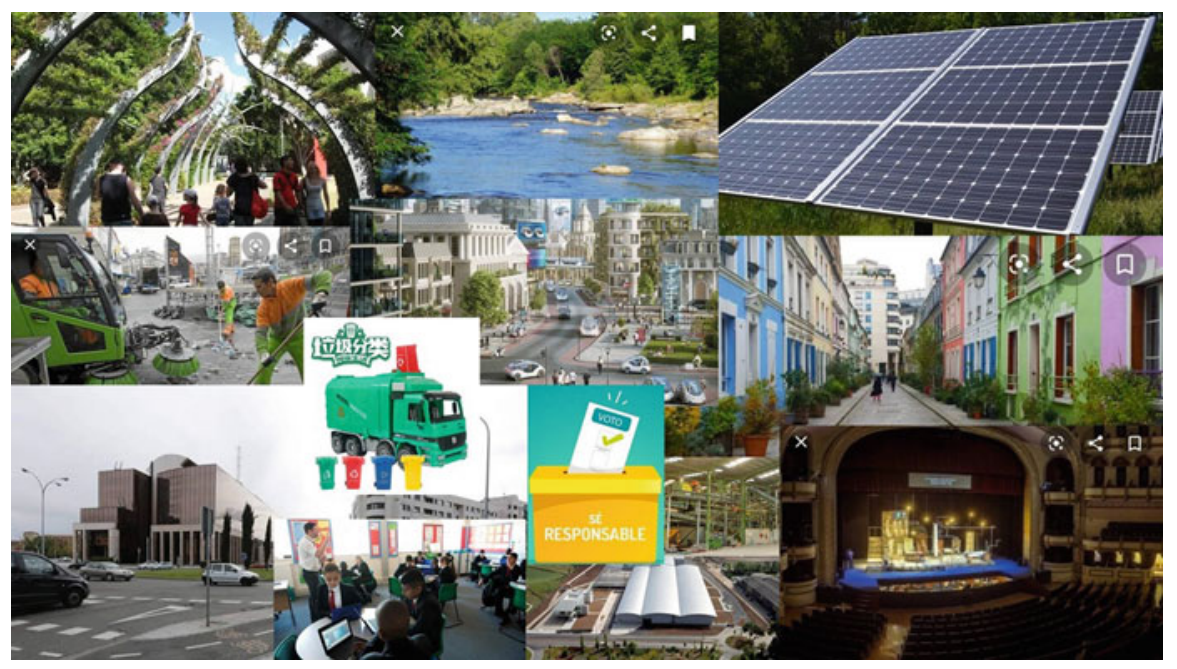

Fig. 12 Vision 1: Piura 2030

\section{Ambiguity}

Stakeholder visits in Manila and Piura in the offices of the institutes provided an insight for participants to understand perspectives from stakeholders of the 


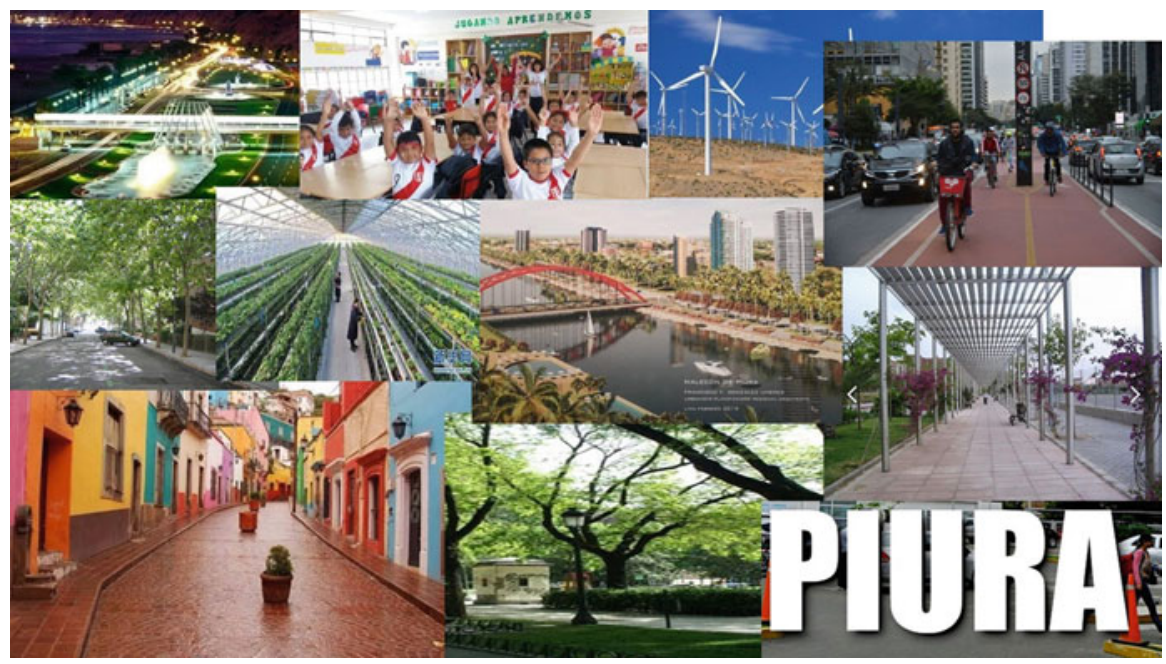

Fig. 13 Vision 2: Piura 2030
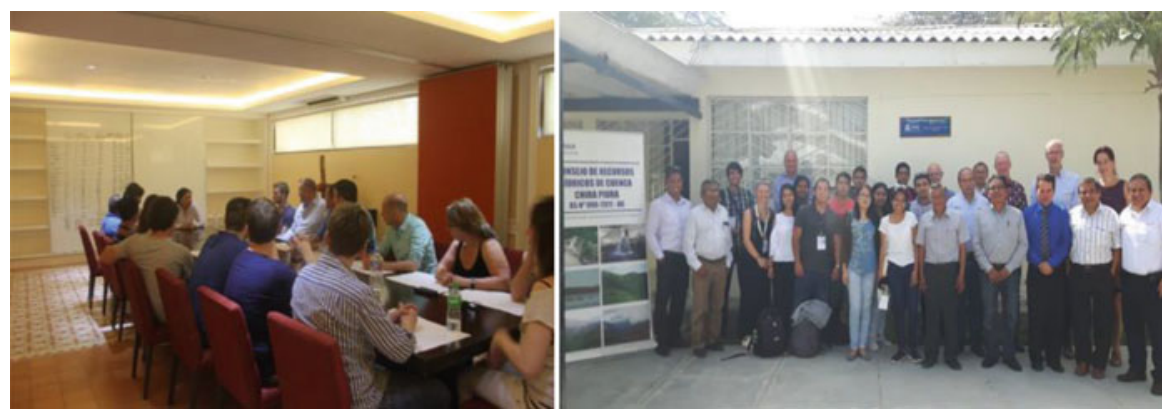

Fig. 14 Stakeholder visits in Manila (left) and Piura (right)

responsible authorities (or partly) of the addressed challenge. Simultaneously, stakeholders had insight in the critical questions of participants and could share their knowledge and experience in dealing with the presented challenge (Fig. 14).

The visits elucidated how authorities are already dealing with solid waste problems in the city and demonstrated that authorities have a willingness to address this challenge. This has been a similar experience in Piura, in which the authorities demonstrated how they handled the challenge of flooding and what work already has been done in that area. More trust in the work of the authorities and a mutual understanding about the complexities of the challenge created relationships among stakeholders and participants. Furthermore, the demonstrated interest of participants into the work of the authorities increases awareness and a sense of urge. 


\section{Decision-Making}

Two final decisions on ideas, based on the collected data and workshops, were found by participants in the ClimateCafés. During the design workshops, an innovative design was developed by Dutch-Philippine participant teams to catch solid waste from the rivers and Peruvian participants to design an integrated urban area to prevent flooding (Figs. 15 and 17).

The participants of the first succession in Manila presented the design during a closing meeting with officials from the Philippines. The participant of the Peruvian ClimateCafé presented to representatives of international water authorities during a mini-symposium. In the second succession of Manila, the innovative product was further designed in detail prior to implementation in the polluted rivers of Pateros and in the Pasig River.

A floating sausage or "Longganisa" (Philippine translation for sausage) was designed (Boogaard et al. 2016) in the first succession and constructed in the second to catch solid waste by using the flow of water in Manila (Fig. 16). The idea was that
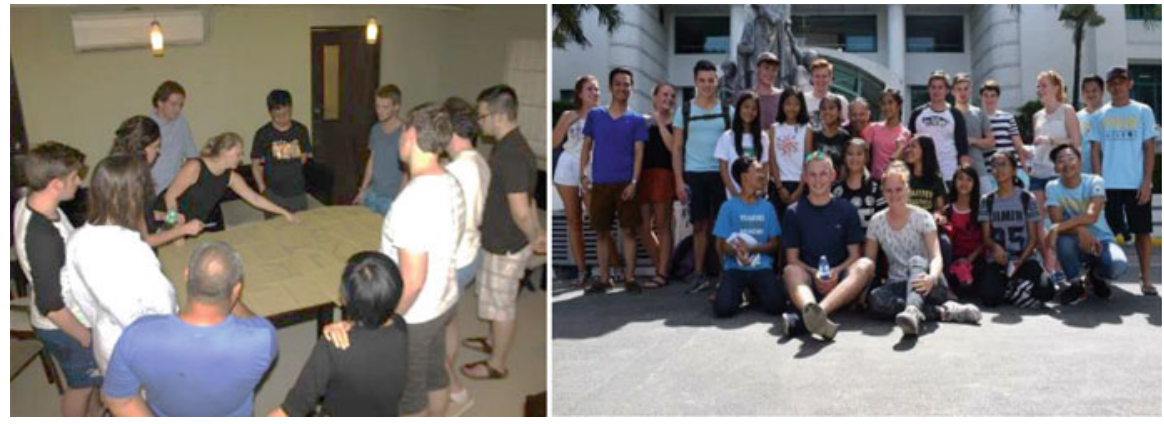

Fig. 15 Design workshop "Longganisa" in April 2016 (left) and 25 Dutch and Philippine participants in October 2016 (right)
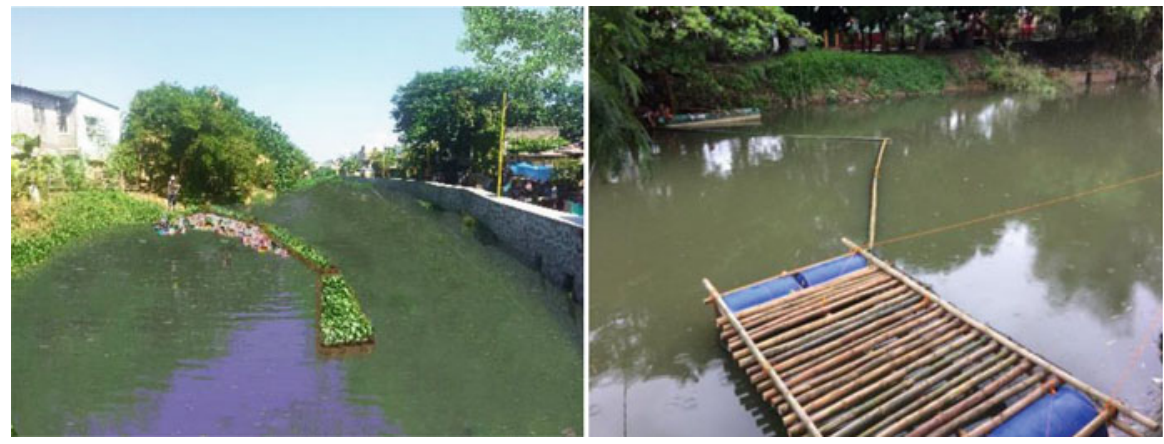

Fig. 16 Innovative "Longganisa" to remove floating waste from rivers. 9b: The Longganisa constructed in November 2016 (in the back is the old way of collecting trash from the river with a boat) 


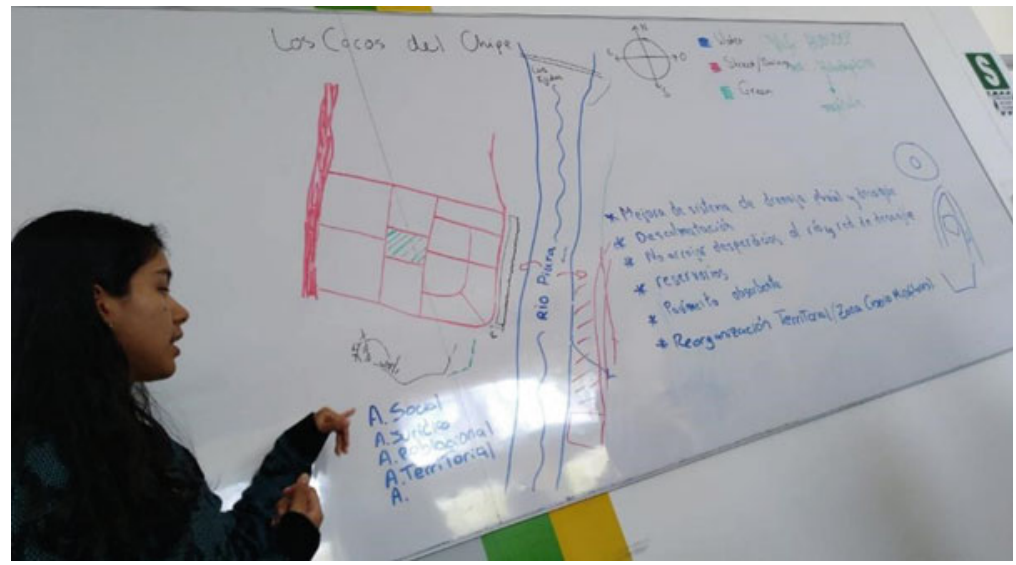

Fig. 17 Student presenting integrated urban planning solutions to Peruvian water authorities during the ClimateCafé mini-symposium

the waste would be collected in the area of a segregation station where the floating waste (such as plastic) could be used to make products as chairs for schools and floating platforms that can be used as bridges or boats. At highly polluted locations, the idea was that the Longganisa would be constructed with filters to remove micropollutants from the water.

An integrated urban design pointed toward a buffer area in an upstream and less populated area of Piura. Together with solutions such as permeable pavements, inspired by the climatescan.org website, and required behavioral change, "do not throw waste in the drainage system," they faced the issue of the area and presented solutions from an integrated perspective (Fig. 17).

\section{Discussions and Results}

\section{The Reduction of Uncertainties}

\section{Epistemic Uncertainty}

The observations are a crucial aspect of ClimateCafés. Participants do not get an introduction before the ClimateCafés, and this is a fast and comprehensive way to introduce the challenge of the ClimateCafé. Collecting data during fieldwork is another crucial aspect of understanding the challenge and learning what data can say about the presented challenge. In both ClimateCafés, few existing adaptation measures were found, which increased the awareness of participants on the current situation and the lack of measures.

Data of the aquatic drones and heat stress in Piura was not used in the ClimateCafé because the data is less accessible and needs to be analyzed by experts 
before it can be used. This data is more suitable for scientific publication compared to the data collected in Manila. This demonstrates the importance of directly usable data collection methods for ClimateCafés. However, biking with sensors and the use of the aquatic drone are innovative data collection tools and got attention from residents which increased the awareness of the ClimateCafé and the challenge that was being addressed.

\section{Ontic Uncertainty}

Ontic uncertainty has been addressed in ClimateCafé Piura. Awareness was generated about the unpredictability of the future, and attention was paid on methods to deal with an unpredictable future. However, the used methods are a normative way of dealing with an uncertain future. A different approach is to use methods which are more exploratory of the future. This would make the mix of "what could happen" and "what should happen" more balanced and increases the added value of dealing with ontic uncertainty.

\section{Ambiguity}

Visits and stakeholder interactions have been key in both ClimateCafés. Having authorities explaining their point of view on the issue is crucial to get a sense of requirements and defining the solution space in which the issue should be addressed. The "meet in the middle" strategy as a combination of "top-down" and "bottom-up" engagement of all stakeholders shows that stakeholders should be engaged in problem framing from the beginning and that (in the Manila case) concrete results are an addition for keeping people involved at different decision levels.

In both ClimateCafés, interviews with local residents were a challenge for participants. In these local contexts, it is not common to interview residents on their opinions and perceptions, and therefore, there was some unwillingness to cooperate. This has led to poor data on perceptions of residents and therefore requires a different approach such as more organized focus group discussions.

\section{Decision-Making}

The presented ideas in Piura are theoretical ideas, unlike that in ClimateCafé Manila, in which the idea was implemented and evaluated in practice. If the definition of adaptation is expanded from "dealing with uncertainties" to "implementing adaptation measures," it enhances the uptake of ideas and demonstrates how ClimateCafé ideas can become tangible. Furthermore, tangible results in an area increase the awareness of adaptation.

\section{ClimateCafé Selection}

\section{Multiple Successions Versus Single Events}

The phrase "more is always better" is certainly true for ClimateCafés. In a single event, it is possible to frame the challenge, to understand the challenge, to collect relevant data on the challenge, and to ideate about solutions. This was done in both 
ClimateCafés. However, the added value of the second edition in Manila elucidated how implementation of solutions can be completed and increase awareness.

\section{Using Participatory Tools}

Quick and dirty data collection tools, with directly analyzable data, are preferred. These types of methods make that data to be used in the same ClimateCafé as it has been collected, enhancing the solutions which are generated during the design workshops. However, the quality of these types of data collection methods is lower than data collected with more advanced high-tech tools. Hence, a mix of these data collection tools is advisable in which direct data collection can be used to calibrate data from more high-tech tools, or the other way around.

\section{Uncertainty Framework}

Separating epistemic, ontic, and ambiguity as types of uncertainty in theory is comprehensible. In practice, the difference is not that obvious. For instance, addressing ambiguity with interviews can also be considered as reducing epistemic uncertainty about perceptions of interviewees. Furthermore, as argued by Zandvoort et al. (2018), dealing with ontic uncertainty could be categorized as doing research as done in epistemic uncertainty. Categorization depends on the own "school" of science and is not set in stone. However, the framework is successful for analyzing the content of both ClimateCafés and make for substantiated criteria. Furthermore, addressing the three types of uncertainty is crucial in anticipating maladaptation practices. An addition to the framework should be about the criteria for the solutions and about the implementation of an idea and an expansion of the definition of adaptation. With such an addition, the framework could not only asses the content of a ClimateCafé but also asses the implementation and impact of a ClimateCafé.

\section{ClimateCafé for Sharing Knowledge, Raising Awareness, and Capacity Building}

The strong knowledge exchange of participants of multiple nationalities in ClimateCafé Manila increased the international knowledge exchange with the lessons learned from both countries. The mix of nationalities of students in ClimateCafé Manila is crucial because it combines local knowledge.

The awareness increases with the number of participants and practitioners. ClimateCafé Manila has achieved the involvement of participants during the two events. Also, awareness increases by the dissemination of a ClimateCafé. Students of the Manila ClimateCafé in the first edition in 2016 had a chance to present their ideas to a high-level audience which gave the idea impact. The fact that the case is imbedded in the curricula of the Water Management course at Rotterdam and Groningen applied Universities enhances the number of practitioners, thus 
dissemination. However, it is important that these kinds of wicked problems are also embedded in the curricula of local universities as well.

Participants of ClimateCafé Piura all had the Peruvian nationality, which limited the international knowledge exchange. The strength of the international knowledge exchange of Manila is therefore more desirable participants from only one nationality.

\section{ClimateCafé and the Quadruple Helix}

It is a long-standing theoretical debate of who is considered a stakeholder and why. In practice the involvement (availability and willingness) of stakeholders to engage in ClimateCafés is key.

The MOU was signed by several high political officials, regrettably this was not a sustainable partnership for up ClimateCafés due to a change of positions with the elections that same year. Lack of foundation and funding later led other cities and countries to learn if ClimateCafés can be set up in a different setting with more focus and an analytic approach.

\section{Conclusion}

ClimateCafé is a multiple-day participatory workshop composed by an international community and powered by individual, corporate, public, and academic climate change adaptation influencers. ClimateCafés have a strong learning by doing approach for international knowledge exchange, raising awareness, and building capacity on climate change adaptation. ClimateCafés focus on local wicked challenges and involve parties from the quadruple helix. Two ClimateCafés, Manila and Piura, demonstrate context-specific data which can be gathered in a short period of time in which participants work together in a multidisciplinary and (in Manila) international teams. ClimateCafé Manila resulted in a practical and implementable idea "the Longganisa" to collect waste in heavily polluted rivers. ClimateCafé Piura resulted in a practical and integrated urban planning idea to reduce flooding and heat stress in the Los Cocos area. Tools for sharing knowledge, such as ClimateScan, are crucial for inspirational purposes, and participatory data collection methods provide direct insight in the addressed challenge.

The content of ClimateCafés contains four blocks, each addressing a different type of uncertainty to come up with innovative solutions for climate adaptation. By using the four different blocks proposed in this framework, it is possible to find climate change adaptation solutions. The blocks give structure on which knowledge is addressed and balance the types of uncertainties that are reduced by this knowledge. Therefore, the framework provides structure and guidance on why certain data collection methods and workshops are included in a ClimateCafé, which reduces the chance of maladaptation. 
ClimateCafés can aid young professionals with different backgrounds, such as urban planners, water management and landscape architects, designers, and many more, in managing sustainable climate adaptation for resilient cities. The dynamic methodology is always in development, and the evaluation of early ClimateCafés leads to improvements along the road, giving a clear direction for further development of this concept for capacity building, knowledge exchange, and bridging the gap between disciplines for climate adaptation.

\section{References}

Bloemen P, Reeder T, Zevenbergen C, Rijke J, Kingsborough A (2018) Lessons learned from applying adaptation pathways in flood risk management and challenges for the further development of this approach. Mitig Adapt Strateg Glob Chang 23(7):1083-1108

Boogaard F, Venvik G (2019) Knowledge exchange on climate adaptation best management practices for sustainable water management in Resilient Cities, international conference cities, rain and risk, 12-14 June 2019, Malmo, Sweden

Boogaard FC, Vojinovic Z, Heikoop R (2016) Storm water and wastewater management for improving water quality. In: Proceedings - global water safety conference, Philippines, April 25-29, 2016

Boogaard F, Tipping J, Muthanna T, Duffy A, Bendall B, Kluck J (2017) Web-based international knowledge exchange tool on urban resilience and climate proofing cities: climatescan. In: 14th IWA/IAHR international conference on urban drainage (ICUD), 10-15 September 2017, Prague

Boogaard FC, Venvik G, Pedroso de Lima RL, Cassanti AC, Roest AH, Zuurman A (2020) ClimateCafé: an interdisciplinary educational tool for sustainable climate adaptation and lessons learned. Sustain 12:3694

Bremer S, Meisch S (2017) Co-production in climate change research: reviewing different perspectives. Wiley Interdiscip Rev Clim Chang 8(6):e482

Brugnach M, Dewulf A, Pahl-Wostl C, Taillieu T (2008) Toward a relational concept of uncertainty: about knowing too little, knowing too differently, and accepting not to know. Ecol Soc 13(2):30

Carayannis EG, Campbell DFJ (2009) Mode 30 and 'quadruple Helix': toward a 21st century fractal innovation ecosystem. Int J Technol Manag 46:201-234

Climate Scan. Available online: http://www.climatescan.org. Accessed 10 Dec 2019

ClimateCafeNews Page. Available online: https://climatecafe.nl/news/. Accessed 6 Dec 2019

Delta Talent (2016, September 30). Delta Talent Academy in volle gang. Delta Talent. Retrieved from http://www.deltatalent.nl/nieuws/delta-talent-academy-volle-gang

Global Commission on Adaptation Adapt now: a global call for leadership on climate resilience. Global Center on Adaptation, Groningen/Rotterdam 2019. Available online: https://cdn.gca.org/ assets/2019-09/GlobalCommission_Report_FINAL.pdf. Accessed 30 May 2020

Haasnoot M, Kwakkel JH, Walker WE, ter Maat J (2013) Dynamic adaptive policy pathways: a method for crafting robust decisions for a deeply uncertain world. Glob Environ Chang 23 (2):485-498

Heikoop R, Boogaard F (2018) Research results City ClimateScan Rotterdam, adaptation futures 2018 dialogues 661 for solutions. In: 5 th international climate change adaptation conference, Cape Town, 662:18-21 June 2018. https://openbooks.uct.ac.za/uct/catalog/view/AF18/27/925-1

Intergovernmental Panel on Climate Change (2019) IPCC special report on climate change, desertification, land degradation, sustainable land management, food security, and greenhouse gas fluxes in terrestrial ecosystems. Summary for policymakers. IPCC, Geneva. Available online: https://www.ipcc.ch/report/srccl/. Accessed 30 May 2020 
Koedinger KR, Kim J, Jia JZ, McLaughlin EA, Bier NL (2015, March). Learning is not a spectator sport: doing is better than watching for learning from a MOOC. In: Proceedings of the second (2015) ACM conference on learning@ scale. ACM, pp 111-120

Lima R, Boogaard F, de Graaf-van Dinther R (2019, December) This is how aquatic drones are supporting water management, GCA 13. https://gca.org/solutions/this-is-how-aquatic-dronesare-supporting-water-management

Masters K (2013) Edgar Dale's pyramid of learning in medical education: a literature review. Med Teach 35(11):e1584-e1593

RIVM (author) Schets FM, v. W. (2007) The microbiological quality of the water in the Amsterdam canals. Bilhoven

Tipping J, Boogaard F, Jaeger R, Duffy A, Klomp T, Manenschijn M (2015) Climatescan.nl: the development of a web-based map application to encourage knowledge-sharing of climateproofing and urban resilient projects, International Waterweek, 3 November 2015, Amsterdam

UN Sustainable Development Goals, Sustainable Development goal Page. Available online: https:// sustainabledevelopment.un.org/sdgs. Accessed 6 Dec 2019

Wollenberg E, Edmunds D, Buck L (2000) Using scenarios to make decisions about the future: anticipatory learning for the adaptive co-management of community forests. Landsc Urban Plan 47(1-2):65-77

Zandvoort M, Van der Vlist MJ, Klijn F, Van den Brink A (2018) Navigating amid uncertainty in spatial planning. Plann Theory 17(1):96-116 